\title{
Contact Dermatitis Due To Alternative Treatment Methods: Four Case Reports
}

\section{AlternatifTedavi Yöntemlerine Bag̃lı Gelișen Kontakt Dermatitis: Dört Olgu Raporu}

\author{
Sevdegül Karadaș ${ }^{1}$, Hayriye Gönüllü', İrfan Aydın², Mehmet Reșit Öncü ${ }^{3}$ \\ 'Department of Emergency Medicine, Faculty of Medicine, Yüzüncü Yıl University, Van, Turkey \\ ${ }^{2}$ Clinic of Emergency Medicine, Adıyaman State Hospital, Adıyaman, Turkey \\ ${ }^{3} \mathrm{Clinic}$ of Emergency Medicine, Van Training and Research Hospital, Van, Turkey
}

\begin{abstract}
Herbal medicines are commonly used in the eastern regions of Turkey, especially in the treatment of rheumatic complaints. In addition, the use of various foods and drinks for cosmetic purposes is increasing among Turkish people. Despite this extensive use of alternative treatment methods for medical and cosmetic purposes, comprehensive research is still required due to the severe local and systemic adverse effects of these treatments. Here, cases of phyto contact dermatitis due to "Ranunculus kotchy boiss" and "Urtica" and irritant contact dermatitis associated with butter are presented.
\end{abstract}

Keywords: Irritant contact dermatitis, phyto contact dermatitis, alternative treatments

Received: 16.08.2011 Accepted: 17.11.2011

\section{ÖZET}

Ülkemizin dog̃u bölgelerinde özellikle romatizmal șikayetlerin tedavisi için yaygın olarak kullanılmaktadır. Ek olarak deg̃ișik yiyecek ve içeceklerin kozmetik amaçlı kullanımı insanlar arasında artış göstermektedir. Medikal ve kozmetik amaçlı alternatif tedavi metotlarının kullanımının artmasına rag̃men lokal ve sistemik ciddi yan etkilerinden dolayı kapsamlı araștırmalara ihtiyaç duyulmaktadır. Burada 'ranunculus kotchy boiss' ve 'urtica' ya bag̃lı gelișen fito kontakt dermatitis ve tereyag̃ı sebebiyle gelișen irritan kontakt dermatitis olguları sunuldu.

Anahtar Kelimeler: İritan kontakt dermatitis, fito kontakt dermatitis, alternatif tedaviler

Geliş Tarihi: 16.08.2011 Kabul Tarihi: 17.11.2011

\section{Introduction}

Alternative treatment methods other than medicinal drugs are frequently used for the treatment of numerous diseases around the world (1). It has been observed that herbal methods are widely used for medical purposes, particularly for rheumatic diseases, and are increasingly used in the cosmetic field $(2,3)$.

In this study, four cases of phyto contact dermatitis and irritant contact dermatitis are presented. We aimed to draw attention to the irritating effects of tropical plants and nutrients used for treatment and cosmetic purposes in alternative medicine.

\section{Case Reports}

\section{Case 1}

A 69-year-old female patient was admitted to the emergency service with complaints of swelling, rash and discharge on the left knee. It was found out that the patient, to relieve joint pain, had ground up the plant "kotchy boiss" from the Ranunculus family, which is also known as buttercup (Figure 1), and applied it to the diseased knee approximately 12 hours ago, upon the advice of neighbors. The examination identified erythematous, occasionally bullous and flowing lesions on the left knee. The patient, with stable vital findings and without other pathologies in other examination findings, was considered to have phyto contact dermatitis associated with "Ranunculus kotchy boiss". Treatment was initiated with wet cloth application, oral and topical antibiotics and oral anti-histamines. The patient, with regressed lesions, was discharged on the fourth day. 


\section{Case 2}

A 60-year-old female patient was admitted to the emergency service with complaints of rash, pruritus and increased temperature on both legs. It was found that the patient, to relieve joint pain, had ground up the plant "kotchy boiss" from the Ranunculus family, which is also known as buttercup (Figure 1), and applied it to both knees and kept them covered five days prior, upon the advice of herbalists. The examination identified increased temperature, erythematous and sporadic lesions with exploded bulla around both knees (Figure 2). The patient, whose other examination findings and routine laboratory tests were normal, was considered to have phyto contact dermatitis associated with "Ranunculus kotchy boiss". Treatment was initiated with wet cloth application, oral and topical antibiotics and oral anti-histamines. The patient, with enhanced lesions, was discharged on the ninth day.

\section{Case 3}

A 40-year-old female patient was admitted to the emergency service due to swelling, rash and increased temperature on the right leg. It was found that the patient ground up the plant Urtica (Figure 3), which is also known as stinging nettle, and applied it to her right knee and opened the bandage two hours later, upon the advice of her mother. The examination identified a lesion with hyperemic, sporadically exploded bulla and scar formation, starting from the right lower femoral area and continuing up to the upper third of the leg (Figure 4). The patient, with stable vital findings and without pathologies in other examination findings, was considered to have phyto contact dermatitis associated with Urtica. The treatment was started with wet cloth application, oral and topical antibiotics, oral

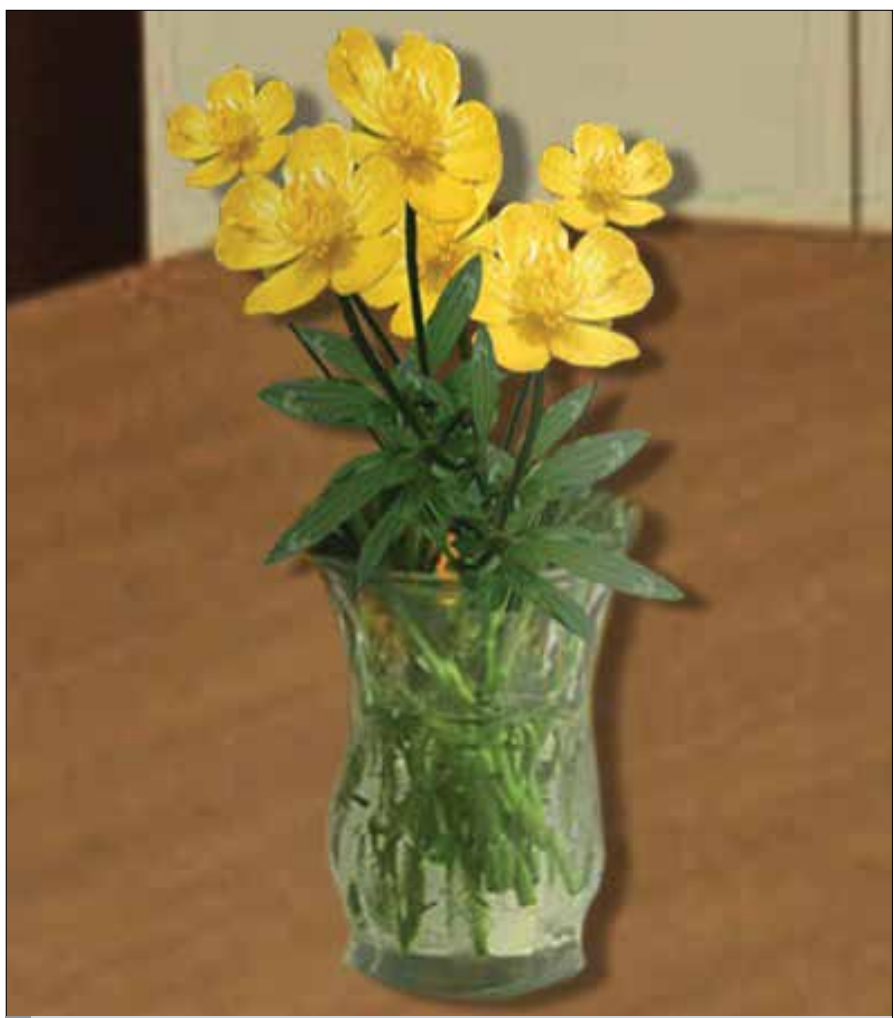

Figure 1. "Kotchy boiss" from the Ranunculus family

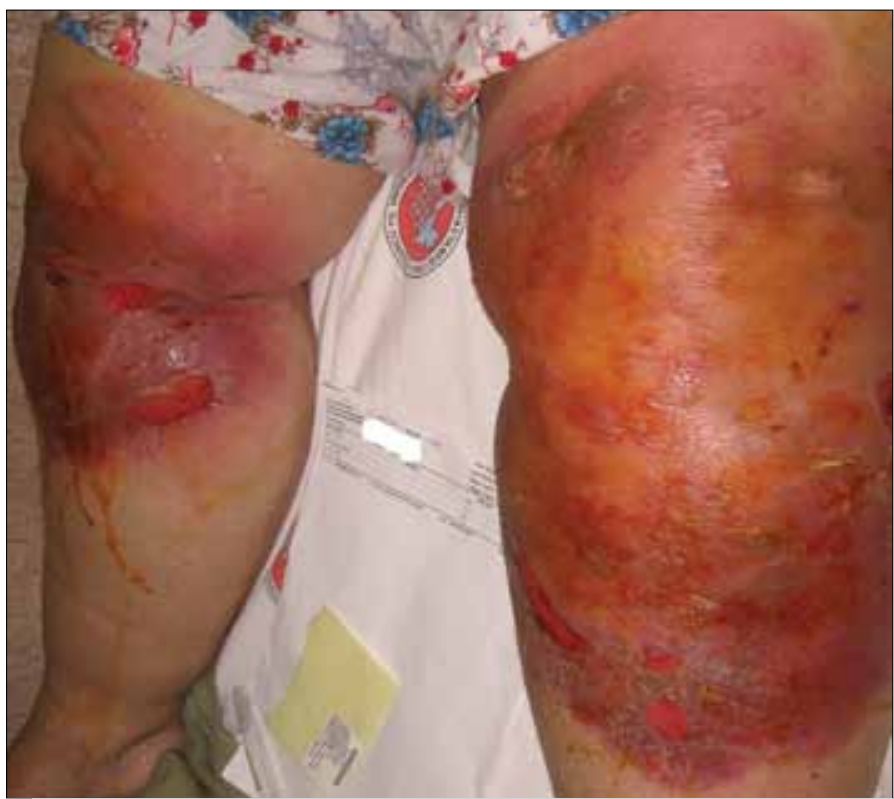

Figure 2. Erythematous and sporadic lesions with exploded bullous around both knees

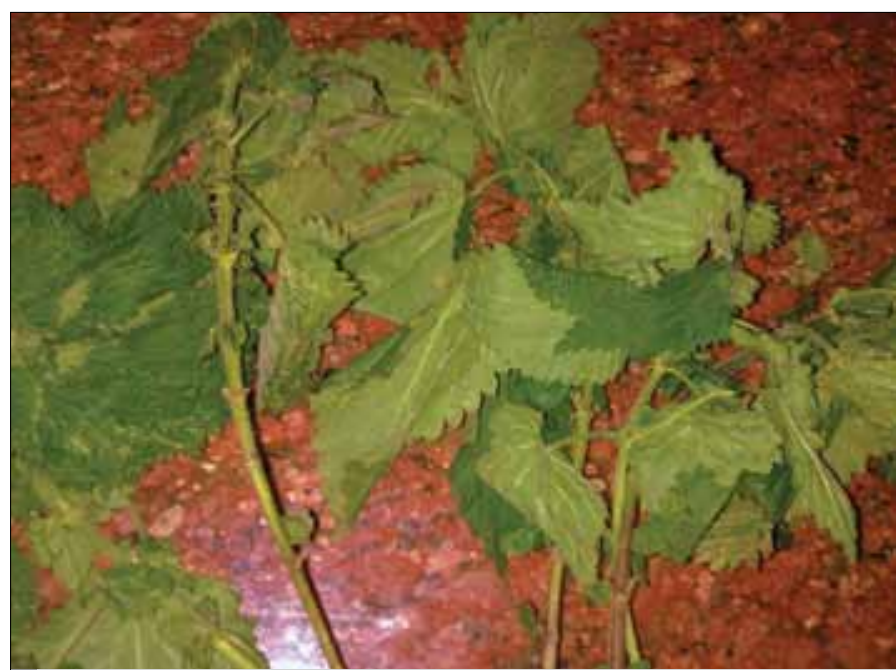

Figure 3. The plant Urtica

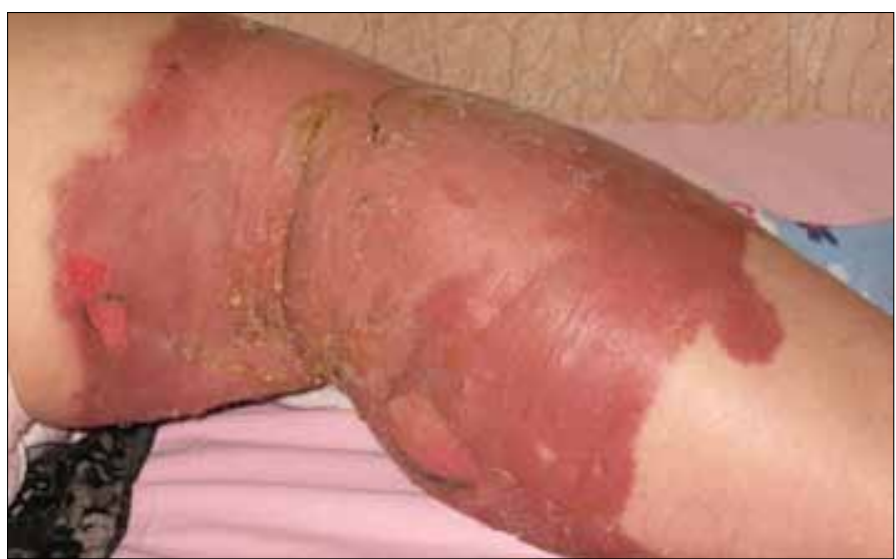

Figure 4. A lesion with hyperemic, sporadically exploded bullous and scar appearance, on the right leg 
anti-histaminic and analgesic. The patient was discharged with advice on the third day.

\section{Case 4}

A 36-year-old female patient was admitted to the emergency service due to the development of skin eruptions and pruritus after applying butter on her body, which she had heard to be good for the skin via communication channels. The examination identified an extensive urticarial eruption across the body (Figure 5). The patient, whose other examination findings were normal, was considered to have irritant contact dermatitis associated with butter. The treatment was started with i.v. antihistamines and i.v. steroids. The patient, whose lesions regressed in two to three hours, was discharged with oral antihistamines.

\section{Discussion}

It is known that herbs are extensively used as an alternative to medical treatment (1). In Turkey, many herbal treatments are frequently used, particularly in the treatment of rheumatologic arthralgia in various indications (2). Although these treatment methods have certain clinical advantages, they may sometimes lead to severe adverse effects (4).

The plant family of Ranunculus grows in the eastern regions of Turkey. It has irritating properties due to the presence of innocuous glycosides and ranulin in its leaves. As a result of crushing, tearing or crumpling of the plant, a volatile and irritating gas is produced by an enzymatic reaction with these substances. The generated protoanemonin is spontaneously polymerized and transformed into innocuous anemonin and its derivatives, leading to subepidermal bleeding in the skin. Subepidermal vesicles, caused by exposure to this plant, are caused by an inhibition of the acantholytic effect of cantharidin by protoanemonin $(5,6)$. In cases 1 and 2, rash, increased temperature and vesicles/bullous appearance was observed after topical application of ground Ranunculus. Emsen reported a case

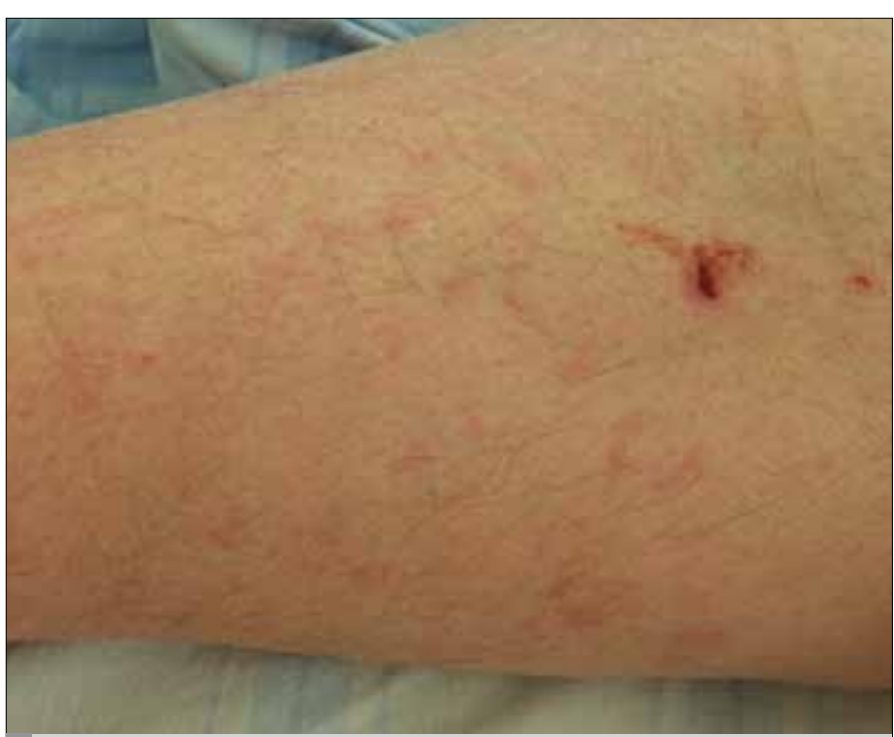

Figure 5. Urticarial eruption across the body of phyto contact dermatitis which resulted in death due to similar application of Ranunculus as in our cases, leading to local infection followed by septic shock (7). Furthermore, cases of phyto contact dermatitis that developed following topical application of plants of the Ranunculus family to relieve rheumatic complaints, in a similar fashion to our cases, have been presented in literature $(8,9)$. The first and second cases in our study were due to topical application of a plant from the Ranunculus family, which is also known as buttercup these reactions resolved completely.

The plant Urtica, which is colloquially known as the stinging nettle, grows abundantly on wall sides and ruins. It has etiolated, oval or heart-shaped, light green leaves $2-4 \mathrm{~cm}$ in length, with serrated sides and irritating villi. Used in food, paints and cosmetics for centuries due to its rich chemical content, the stinging nettle is extensively used in the treatment of rheumatic and other diseases in Turkey $(10,11)$. Anderson et al. (12) have reported that contact with stinging nettle leads to pruritus, dermatitis and urticaria, and that the reaction is associated with certain substances released by the scape and leaves of the plant. There are cases of contact dermatitis in the literature that were caused by hand contact with artichoke, sumac and ivy $(13,14)$. However, the third case in this study, unlike the one in literature, involved the application of stinging nettle on the knee for treatment purposes.

We believe that the use of various food and drinks for cosmetic purposes, particularly by women, is increasing day by day due to information provided by the media. Our fourth case in the present study applied butter, which is used in cooking, on her body believing that it would improve the brightness and firmness of her skin, and consequently developed irritant contact dermatitis. A review of the literature did not identify any information on such use of butter.

\section{Conclusion}

Despite extensive use of alternative treatment methods for medical and cosmetic purposes, comprehensive research is still required due to the severe local and systemic adverse effects of these treatments. The use of herbal treatment methods should also be investigated in cases admitted to emergency services with erythematous and vesicle/bullous lesions.

\section{Conflict of interest}

No conflict of interest was declared by the authors.

\section{References}

1. Mantle D, Gok MA, Lennard TW. Adverse and beneficial effects of plant extracts on skin and skin disorders. Adverse Drug React Toxicol Rev 2001; 20: 89-103

2. Polat M, Oztas P, Yalcin B, Tamer E, Gur G, Alli N. Contact dermatitis due to Allivum sativum and Ranunculus illyricus: two cases. Contact Dermatitis 2007; 57: 279-80. [CrossRef]

3. Schempp CM, Schöpf E, Simon JC. Plant-induced toxic and allergic dermatitis (phytodermatitis). Hautarzt 2002; 53: 93-7. [CrossRef]

4. Abadog̃lu Ö. Allergic Skin Diseases and Alternative Medicine. Asthma allergy immunology 2006; 4: 80-7.

5. Tanker N, Koyuncu M, Coșkun M. Pharmaceutical botany, Ankara, Ankara University. Faculty of Pharmacy Publications 1998; 9: 222-9. 
6. Prieto JM, Recio MC, Giner RM, Máñez S, Ríos JL. Pharmacological approach to the pro- and anti-inflammatory effects of Ranunculus sceleratus L. J Ethnopharmacol 2003; 89: 131-7. [CrossRef]

7. Emsen IM. Plant-Based with interesting and deadly Buttercup (Ranunculus: Wedding Flower) Burn. Journal of Turkish Plast ve Reconstr Est Surg 2006; 2: 142-3.

8. Metin A, Calka O, Akdeniz N, Behçet L. Phytodermatitis from Ceratocephalus falcatus. Contact Dermatitis 2005; 52: 314-6. [CrossRef]

9. Yenidünya MO, Can Z, Demirseren ME. A burn from a plant. Plast Recontr Surg 1999; 103: 335-6. [CrossRef]
10. Konrad L, Müller HH, Lenz C, Laubinger H, Aumüller G, Lichius JJ. Antiproliferative effect on human prostate cancer cells by a stinging nettle root (Urtica dioica) extract. Planta Med 2000; 66: 44-7. [CrossRef]

11. Ayan AK, Çalışkan Ö, Çırak C. Economical Importance of Stinging Netle (Urtica spp) and Its cultivation. J of Fac of Agric OMU 2006; 21: 357-63.

12. Anderson BE, Miller CJ, Adams DR. Stinging nettle dermatitis. Am J Contact Dermatitis 2003; 14: 44-6.

13. Pipili C, Cholongitas E, loannidou D. Phytocontact dermatitis caused by artichoke: an exceptionally rare case. Clin Exp Dermatol 2009; 34:534-5. [CrossRef]

14. Boelman DJ. Emergency: Treating poison ivy, oak, and sumac. Am J Nurs 2010; 110: 49-52. [CrossRef] 